\title{
Weisure - Phenomenon, Lifestyle, or Vice? Martina Kočerová
}

\begin{abstract}
The article deals with the phenomenon of weisure and the changes brought by it in the area of leisure. It is a theoretical study aimed at showing the role of leisure-time pedagogy in modern Western society where the boundary between work time and leisure is loosened.

The conclusion given from the perspective of leisure time pedagogy states that it is desirable to influence an individual during his childhood as the basis of personality and value orientation are formed in this period. Leisure time pedagogy does not consider leisure time to be a space in time. It is rather an important life attitude that significantly influences the balance of life of every individual and also of society as a whole. In the area of the prevention of the weisure lifestyle, leisure time pedagogy should focus especially on the development of leisure time competences, value education, critical thinking, and socialisation. Conversely, leisure education should not focus on the mere realisation of activities (despite their attractiveness, entertainment, or meaningfulness). If the educational action in leisure time is replaced by the mere fulfilment of free time (choosing the activities only), leisure time instrumentalisation and the development of the weisure lifestyle can occur. Instead of learning how to deal with freedom, responsibility, and perseverance, and instead of looking for meaning, the child learns to consume leisure activities, entertain himself, and selectively choose activities according to the mood or fashion. Leisure time, as a time category, has not disappeared from a person's life, but the essence of leisure time (which is largely influenced by instrumentalisation and by pedagogy of leisure time) is being erased. Leisure time receives the character of an obligation, and its potential is reduced that way. It is this development that underscores the importance of leisure time pedagogy which should focus its efforts not only on children and young people but also on the education of parents and leisure time educators who are involved in instrumentalisation and the pedagogical forming of leisure time in many ways.
\end{abstract}

Keywords: value education, leisure time instrumentalisation, intravidual, leisure time pedagogy, pedagogical forming of leisure time, leisure time, leisure time competence, weisure

\section{Introduction}

Even if the phenomenon of weisure is quite frequently discussed in the world, it does not seem to attract much attention in the Czech environment. If it is given space in the professional press, it is mainly in the field of sociology, not pedagogy (which is also true for most foreign treatises). 
However, this does not mean that Czech society has not been affected by this phenomenon. As in other technologically advanced countries, the use of the newest technologies is also a common part of life in the Czech Republic. Even in the Czech Republic, a clear border between many areas is disappearing. This is true for work and leisure time, private and public spheres, job activities and leisure activities.

Leisure time is still for many people a time period intended for possible or necessary relaxing after work, either in an active or passive way. For others it is a time of self-realisation and realisation of unfulfilled needs, desires, and wishes - things which cannot be fulfilled during the time of work. Many people want to have fun during their leisure time and enjoy life and - perhaps paradoxically - they want to forget about life-related concerns. However, an increasingly large group of people feel that they cannot afford to postpone their duties and have some leisure time. Therefore, they are still online. There is also a growing range of people, especially young ones, who consider leisure activities a part of their job. How people think of their leisure time and what they expect from their leisure time shows their concept of life as a whole.

Weisure and changes in the life structure of modern Western society are in a reciprocal relationship. While the lives of today's grandparents have been clearly structured in terms of time, space, and social roles, the lives of today's young people show significant changes. Boundaries are being erased, and modern technology not only allows one to do several things at once but it allows one to be in several places at the same time. It is also possible to be simultaneously at several different time zones (with different people, in different cultures). Work and fun are blending together. Sometimes, they could be even completely merged, and then it is not clear what is work and what is fun. One loses clear boundaries and even stops being sure of one's own self. Although he has considerable freedom, he cannot manage it. This is caused by a lack the reference frameworks which are so very needed for decision-making and identity building. An intravidual arises - an individual who cannot distinguish boundaries, one who is uncertain and has doubts. ${ }^{1}$

The boundaries between work and leisure time disappear for some people. Such a situation is causing the questioning of leisure time and its importance and place. Nevertheless, the importance of leisure time pedagogy is not diminished. On the contrary, the lifestyle of weisure brings new challenges into leisure time pedagogy and these have to be dealt with.

\section{What Is Weisure}

In 2009, the CNN website published the article 'Welcome to the "Weisure" Lifestyle. ${ }^{2}$ The article dealt with the new trend called weisure in English. ${ }^{3}$ Weisure is a phenomenon characterised by blurring the boundaries between work and leisure time. It was first described in the US. However, it does not affect American society only. It occurs anywhere where modern technology and virtual reality have permeated human life. It is a phenomenon that we can also see in contemporary Czech society.

1 Cf. Dalton CONLEY, Elsewhere, U.S.A.: How We Got from the Company Man, Family Dinners, and the Affluent Society to the Home Office, BlackBerry Moms, and Economic Anxiety, New York: Pantheon Books, 2008, pp. 156-171; cf. @ Dalton CONLEY, Rich man's burden, The New York Times, September 2, 2008, available at: https://www.nytimes.com/2008/09/02/opinion/02conley.html; cf. Gilles LIPOVETSKY, Les temps hypermodernes, Paris: Editions Grasset \& Fasquelle, 2004, pp. 8-148; cf. Manfred SPITZER, Cyberkrank!, München: Droemer Verlag, 2015, pp. 25-46.

2 Cf. () Thom PATTERSON, Welcome to the 'weisure' lifestyle. CNN. May 11, 2009, available at: http://edition.cnn.com/2009/LIVING/ worklife/05/11/weisure/?iref=nextin.

3 It is a combination of two English words - work and leisure. In the Czech language, there is no language equivalent to weisure. Dictionary. university (online), keyword: weisure. 
The term weisure was first used by American sociologist Dalton Conley. In his book Elsewhere, U.S.A. ${ }^{4}$, he compares the lifestyle of his grandparents, parents, and his contemporaries. He follows the differences, in particular, between the time spent at work and leisure time. Their boundaries have gradually become loose. Considering the grandparents, the boundary is quite clear. Their working time was significantly different from the leisure time. The same is valid for working and leisure time activities. In the case of the contemporary generation, we often do not find this clear boundary. This is true for both time division and activities (typical working activities or typical leisure time activities). While the grandparents were working in order to have rest and enjoy their hobbies at the time of retirement, a contemporary person works all the time. The life of the grandparents was structured. It was clear when and where one worked - when, where (and with whom) one spent his leisure time. A contemporary person moves from place to place very quickly. Thanks to modern technology, he can be in several places simultaneously. The time and space boundaries are blurred and, in addition to that, one can work and have fun at the same time - to be or not to be at work at the same moment. ${ }^{5}$

Also, the traditional division of roles in the family has been disappearing. Previously, it was clear who was cooking, who took care of the garden, house, or household. Today, family members usually eat each day separately and away from home. Time spent together at the table is very limited. Children are picked up from school and then driven to their afterschool activities by one of the parents, who has a less busy schedule. If the family is together, it is very often as a physical presence only as the individual family members are online somewhere else or are disturbed by phone calls, emails, etc. The contemporary modern society spends most of the time working regardless of one's physical location. ${ }^{6}$

The changes mainly concern the three life spheres - economy, family, and technology. These changes give birth to a new type of person called an intravidual. ${ }^{7} \mathrm{He}$ is literally attacked with innumerable stimuli in one single moment. It seems as if he is living in more worlds at the same time. Of course, not all people live this lifestyle. The influence of those who do, though, changes the playing field for others. It is supported by the fact that the modernist divisions (discussed in the next chapter), that is, home - office, work - leisure time, public - private, and even me others, no longer apply. The boundaries between work and home are disappearing, technology is shaping family life, work is pervading leisure time, and vice versa. Activities and social spaces are becoming ambiguous. What is work and what is fun, or what is a work tool and what a toy, is no longer clear. The blurring of borders results in constant unstableness and uncertainty. ${ }^{8}$ As a consequence of the weakening of the established behaviour (in modern society), the deepening of personalisation (accompanying the postmodern period), and putting emphasis on action based on personal choice and responsibility, it is perhaps not clear where the individual should stand and what he should do. ${ }^{9}$

Especially those who work mentally and use modern technology for work are influenced by the

Cf. CONLEY, Elsewhere..., p. 31.

Cf. ibid., pp. 141-155; cf. LIPOVETSKY, Les temps..., pp. 11-30.

Cf. CONLEY, Elsewhere..., pp. 141-155; cf. LIPOVETSKY, Les temps..., pp. 11-43.

This is a person who does not distinguish the boundaries between home and work. His attention is constantly focused on the diverse flows of information. Definition - Of. Community dictionary by Farlex (online), keyword: intravidual.

8 Cf. CONLEY, Elsewhere..., pp. 141-155; cf. PATTERSON, Welcome...; cf. ( ) Eric STODDART, 'Fuelled by dreams and powered by imagination': Considering digital technologies through the lens of a theology of play. Practical Theology 1/2015, available at: https:// doi.org/10.1179/1756074815Y.0000000002, pp. 19-40; cf. Manfred SPITZER, Demencia digital, Barcelona: Ediciones B, 2013, pp. 27-103; cf. SPITZER, Cyberkrank!..., pp. 25-46.

9 Cf. Gilles LIPOVETSKY, Lére du vide. Essais sur l'individualisme contemporain, Paris: Editions Gallimard, 1983, pp. 7-99. 
weisure lifestyle. It is a group of people interconnected by social networks. Such networks are ambivalent and can be both a source of entertainment and a working environment at the same time. The online world members can be, and often are, both friends and business partners. There are also children and young people whose environment is inherently connected with modern technologies. Undoubtedly, the technology forms the basis for their future lifestyle. ${ }^{10}$

\section{Weisure and the Modern Concept of Leisure Time}

Weisure-time is a two-way concept. It describes a lifestyle of people who work in their leisure time. For a holiday, such people go to places with an internet connection only. In this way, they can still be connected, and influence work matters if necessary. Eventually, they spend weekends at work. In recent years, however, the other variant of leisure time and work blending has increased. Leisure time activities (entertainment, time spent on social networks, chatting with friends) have been done during work. But is it really a new phenomenon? Perhaps, it is more a return to a past concept of life (that is, the concept which was usual before defining the life category of leisure time as we know it in modern society?).

It is possible to meet the concept of leisure time even in antiquity ${ }^{11}$ (in the concept of scholé). At that time, leisure time provided an opportunity for personal thinking, thinking about life, discovering one's own spirituality, and it was also the opposite of physical work. It was not merely a time but a state, a desired way of living, and a way to progress through intellectual, contemplative, and aesthetic activities. It was part of the lifestyle and the quest for quality of life. Nevertheless, it was the privilege of free men. The democratisation of leisure time is a modern phenomenon. ${ }^{12}$

Some modern authors view leisure time as an analogy to the schole. Pieper, ${ }^{13}$ for example, represents leisure time as the inner state of the soul. This state is characterised by non-activity, and it opposes the ideal of labour overestimation (in the sense of the ancient $\sigma \chi 0 \lambda \eta \dot{)}$ ). It is an attitude of celebration representing the direct opposite to effort. This attitude is accompanied by calmness and exclusion from social function. The actual purpose of leisure time is to remain human. This means to understand and realise oneself as a human being who focuses on reality as a whole.

Festivals and holidays, which used to be a time of escape from routine, stress, and the monotony of everyday life, can be considered a predecessor of leisure time. But not only that. During that time spent together, people remembered important events from the history of their tribe or nation, and strengthened their togetherness, their tribal or national identity. There was the awareness of the fact that one belongs to a certain place (that one is not alone but has a history and also a future). At the same time, these events were a time frame as they came at regular intervals throughout the year or life. They were giving the opportunity to stop, recap, contemplate, plan, and prepare for what would come after them. Thus, one could throw down the weight of the past and fix one's eyes on future things in the perspective of one's life as a whole. ${ }^{14}$

10 Cf. CONLEY, Elsewhere..., pp. 141-170; cf. ( ) Fred LEE, Living a life of weisure? WiseBread. Living large on a small budget, May 20, 2009, available at: https://www.wisebread.com/living-a-life-of-weisure; cf. PATTERSON, Welcome...; cf. Robert. A. STEBBINS, New Directions in the Theory and Research of Serious Leisure. New York: Mellen Press, 2001, pp. 13-185; cf. STODDART, 'Fuelled...'; cf. SPITZER, Cyberkrank!..., pp. 141-155.

11 Cf. ARISTOTELES, Etika Níkomachova, Praha: Rezek, 2013.

12 Cf. Christopher R. EDGINTON, Rodney B. DIESER and Donald G. DEGRAAF, Leisure and Life Satisfaction. Foundational Perspectives, Boston: McGraw Hill, 2006, pp. 29-41; cf. Karl MARX, Das Kapital. Kritik der politischen Ökonomie, Berlin: Dietz Verlag, 1959; cf. Jürgen HABERMAS, The structural transformation of the public sphere, Cambridge/Massachusetts: Tha MIT Press, 1991, pp. 141-180.

13 Cf. Josef PIEPER, Muße und Kult, München: Kösel, 1949, pp. 43-50.

14 Cf. Michal KAPLÁNEK (Ed.), Volný čas a jeho význam ve výchově, Praha: Portál, 2017, pp. 6-30. 
According to Maslow ${ }^{15}$ the highest needs of a person are to belong, to acknowledge, to respect, and to fulfil one's life. Apart from this concept, there are also other approaches that are looking for the highest need elsewhere. Frankl, for example, considers the highest need to find what has the deepest and highest value for a person, that is, a final meaning. ${ }^{16}$ The task is to find out what transcends a person. This can only be done if there is a time or attitude leading to contemplation and celebration in a person's life. Lipovetsky ${ }^{17}$ challenges Frankl's opinion. He claims that the process of personalisation (which accompanies postmodern times and the transformation of temporality) has systematically removed everything transcendent. People are left with things which are current and completely subjective. Thus, a postmodern person lives a life that is completely without a goal or meaning. In such a life, he is exposed to a dizzying self-enchantment.

In the Middle Ages, leisure time was associated with traders' market inactivity. At the same time, the Aristotelian tradition was also responding to this idea. It emphasised the contemplative life (vita contemplativa), which should balance the practical life (vita activa). The breaking point came with humanism. It brought the connection of leisure time with the attribute of personal freedom. The humanistic idea was further emphasised by the Enlightenment era. According to Nahrstedt, ${ }^{18}$ the Enlightenment (which accentuated the ideal of freedom) had a decisive influence on the modern concept of leisure time. He based his thoughts on Enlightenment authors. ${ }^{19}$

However, a modern concept of leisure time was formed during the industrialisation period. This period brought a clear definition of working time. After leaving work, people spend time in a private zone. The time after work is filled with leisure activities, and activities with family and friends. The factors that led to the modern division of life into the public and private spheres are the following three: the place of one's employment is different from the place of one's residence; a job description is clearly given; wages are paid for time spent in the workplace or for a fulfilled work task. ${ }^{20}$ While the first two factors were applied in education before industrialisation, ${ }^{21}$ the third is linked to the industrial revolution. Thus, there was a division of life into the public and private sphere, into the time of duty and the leisure time. The period of industrialisation is associated with another factor that has significantly affected the aforementioned distribution of time. It was the length of working time and the right to work leave. The vision of reducing working time and expanding the right to leisure time for all people has already been expressed by the utopian socialists. $^{22}$ It was Marx's ${ }^{23}$ demand for leisure time democratisation, however, which has become one of the objectives of the social movement for social justice. These activities have resulted in a gradual reduction of working time and the establishment of the right to work leave for all. ${ }^{24}$

15 Cf. () Abraham H. MASLOW, A theory of human motivation, Psychological Review 4/1943, available at: http://dx.doi.org/10.1037/ h0054346, pp. 370-396.

16 Cf. Zuzana SVOBODOVÁ, Nelhostejnost: Črty k (ne)náboženské výchově, Praha: Malvern, 2004, pp. 15-28.

17 Cf. LIPOVETSKY, Lére du vide..., pp. 7-99.

18 Cf. Wolfgang NAHRSTEDT, Freizeitpädagogik in der nachindustriellen Gesellschaft, Neuwied/ Darmstadt, 1974, pp. 18-64; cf. Wolfgang NAHRSTEDT, Freizeitpädagogik, in: Helmwart HIERDIES ed., Taschenbuch der Pädagogik, Bd. 1., Baltmansweiler: Pädagogischer Verlag, 1986, pp. 222-235.

19 Cf. NAHRSTEDT, Freizeitpädagogik in der nachindustriellen...; cf. NAHRSTEDT, Freizeitpädagogik..., pp. 18-64; cf. KAPLÁNEK, Volný čas..., pp. 6-30.

20 Cf. HABERMAS, The structural..., pp. 141-180; cf. KAPLÁNEK, Volný čas..., pp. 6-30; cf. Horst OPASCHOWSKI, Pädagogik der freien Lebenszeit, 3. Aufl., Opladen: Leske+Budrich, 1996, pp. 28-56.

21 Cf. Jan A. KOMENSKÝ, Didactica magna, Brno: Komenium, učitelské nakladatelství, s.r.o., 1948, pp. 91-162.

22 Cf. Thomas MORE, Utopia, Indianapolis: Hackett, 1999; cf. Tommaso CAMPANELLA, La città del Sole, Milan: Feltrinelli, 2004; cf. Francis BACON, New Atlantis, Manchester: Manchester University Press, 2002.

23 Cf. MARX, Das Kapital...

24 The International Labour Conference (based on Article 424 of the Treaty of Versailles) was held in Washington from $28^{\text {th }}$ October to $30^{\text {th }}$ November 1919. The proposal of an eight-hour working day and a 40-hour working week was approved. This demand (especially the eight-hour working day) was strongly reiterated at an extraordinary IFTU (The International Federation of Trade Unions) congress 


\subsection{Leisure Time - Residual Time}

Modern times have accentuated discipline. Such an approach has led to standardised behaviour and to the formation of the best production capabilities. ${ }^{25}$ The logical consequence of these emphases was the formation of leisure time in connection with the emergence and development of employment relationships and with duties, especially work duties. ${ }^{26}$ This was also related to the understanding of leisure time, which was mainly associated with relaxing after work, gaining energy for further work, ${ }^{27}$ and doing activities which could not be done during work time. ${ }^{28}$ The abovementioned development has led to changes in the structure of people's lives in modern society (as described in Chapter 1), and to the definition of leisure time as a residual category. As such, leisure time and its value depend on work mainly. ${ }^{29}$

Filipcová ${ }^{30}$ deals with this view of leisure time and connects it with one's possibility to choose activities for this time. She also admits that one can choose to do nothing. This choice (that one 'can' or 'does not have to' do something in one's leisure time), though, is considered a privilege. She argues, to a certain extent, with Petrosjan, ${ }^{31}$ who sees leisure time mainly as a sphere of 'simple reproduction of one's work forces. ${ }^{32}$ Filipcová is not the first author who does not see leisure time as a 'prolonged hand of work'. In 1880, Paul Lafargue published Le Droit à la Parasse (The Right to Be Lazy). ${ }^{33}$ In this written work he defends one's right to freely manage his own time (leisure time included). Filipcová emphasises that

the way of reproduction of work power (at time out of work generally, and during leisure time mainly) influences the work production itself. Man is not just work power, though. To be work power is not his only social or human role. To reduce a person to work power only, it means to make production the only sense and goal of human existence. It would mean that a person lives and exists because he produces. Does it mean that he only exists for production purposes? Such a narrow view of leisure time leads to certain simplified schemes concerning the positive (often called rational, or effective) usage of leisure time. $^{34}$

In her view of leisure time, she does not forget about recreation. ${ }^{35}$ She emphasises that leisure time activities do not have to be connected with some concrete result (with a concrete form) in the first place. The result could be experience, feeling, or knowledge as well. Leisure time forms ways of

in London in 1920. (Data in accordance with: Franz OSTERROTH and Dieter SCHUSTER, Chronik der deutschen Sozialdemokratie, Hannover: Dietz Verlag, 1963, pp. 234 and 256, cited according to Nahrstedt); cf. OPASCHOWSKI, Pädagogik der freien Lebenszeit..., pp. 28-56; cf. Michal KAPLÁNEK, Pedagogika volného času - projekt budoucnosti, nebo slepá ulička?. Pedagogika 1/2010, pp. 12-20; cf. KAPLÁNEK, Volný čas..., pp. 6-30; cf. Hermann GIESECKE, Zur Geschichte der Freizeit und ihrer Erforschung, in: Hermann GIESECKE (Ed.), Freizeit und Konsumerziehung, Göttingen: Vendenhoek u. Ruprecht, 1968, pp. 9-18.

Cf. Gilles LIPOVETSKY, Lempire de l’ephémère. La mode et son destin dans les sociétésmodernes, Paris: Editions Gallimard, 1991.

6 Cf. KAPLÁNEK, Volný čas..., pp. 3-12.

27 Cf. GIESECKE, Zur Geschichte..., pp. 9-18.

28 Cf. HABERMAS, The structural..., pp. 141-180; cf. Horst OPASCHOWSKI, Pädagogik der Freizeit. Grundlegung für Wissenschaft und Praxis, Bad Heilbrunn: Klinkhardt, 1976, pp. 23-56.

29 Cf. KAPLÁNEK, Volný čas..., pp. 6-30.

30 Cf. Blanka FILIPCOVÁ, Člověk, práce, volný čas, Praha: Svoboda, 1966.

31 Cf. S. G. PETROSJAN, Vněrabočeje vremja trudjaščichsja v SSSR, Moskva, 1965, p. 12.

32 Cf. FILIPCOVÁ, Člověk..., p. 50.

33 Cf. Paul LAFARGUE, Le Droit à la Paresse. Éditions de la République des Lettres. Publication numérique (format ePub), 2012.

34 FILIPCOVÁ, Člověk..., p. 50.

35 Cf. ibid., pp. 24-25. 
living and enables participation in the given culture. ${ }^{36}$

Červink ${ }^{37}$ brings a different attribute into the discussion about leisure time. He considers the connection between leisure time and the upbringing of children. In his opinion, family activities (such as cooking, cleaning, shopping, or relaxing in a passive way) cannot be associated with leisure time.

Vážanskýs ${ }^{38}$ points out that people often transfer learned work frameworks into their leisure time and the other way around (the congruent theory of leisure time). He also thinks about leisure time in terms of freedom and one's free choice. However, he sees certain limits to the usage of leisure time. There are work limits, various barriers, and prejudice caused by the application of various work behavioural models in this area of relative freedom.

He speaks about a hypothesis of compliance with the theories of reduction, generalisation, and identity. Besides this theory, there is another one called a hypothesis of contrast with the theories of compensation, relief, and recovery. Both these hypotheses belong to the negative definition of leisure time. They understand leisure time as a space for action which is conditioned by work. This approach towards leisure time assumes that people control and eliminate their emotions at work. In addition, people have to deal with many latent fears, restlessness, uncertainty, and stress. These conditions lead to psychical tension and to internal restlessness. Eventually, one has to compensate for this during one's leisure time as it is a precondition for (and assurance for) health and good psychical state..$^{39}$

There is also a positive definition of leisure time. This approach sees leisure time as an independent life area which has its own value, and provides space for growth, identity and life-meaning searching, true values discovery, self-realisation, and the fulfilment of needs. ${ }^{40}$

The number of differences between the negative and positive approach to leisure time is questionable. Each of them views leisure time differently. Both approaches, though, emphasise the fact that work opposes leisure time. And if both work and leisure time are areas of one single human life, they have a negative relationship, and they cannot be united. The positive approach, though, can become a starting point for a more solid way to leisure time definition which supports the idea of human unity (similar to the approaches that understand man as a unity instead of seeing him as an individual with two antagonistic elements inside - work and leisure time). In such a case, work and leisure time cannot be evaluated as two detached independent areas. Both of them have to fulfil the need for self-realisation, a certain independency, and meaning of life. Such processes support the complex development of personality, and they also support the person's environment.

\subsection{Leisure Time - Leisure}

The historical development of human society has brought the development of all areas of human life (including leisure time). Leisure time as a residue, that is, the time which is left after work (as described in Chapter 2.1), has not been the only approach over time.

In English-speaking countries, known for their Anglo-Saxon scientific approach called leisure studies (or leisure sciences), ${ }^{41}$ we can meet two English terms covering a single term in Czech.

36 Cf. Blanka FILIPCOVÁ, Volný čas a kultura v průmyslovém městěe, Praha: Ústav pro kulturně výchovnou činnost, 1974 , pp. $24-25$.

37 Cf. Antonín ČERVINKA, Volný čas a pracovní den, Nová mysl 11/1962, p. 1292.

38 Cf. Mojmír VÁŽANSKÝ, Základy pedagogiky volného času. 2nd extended edition, Brno: Print-Typia, 2011, pp. 30-32.

39 Cf. ibid.

40 Cf. ibid.

41 Cf. Tony BLACKSHAW, Leisure, London: Routledge, 2010. 
These are free time and leisure. Free time means a sequence of time while leisure is a more complex term. Leisure is sometimes described as an important social, cultural, and economic power which influences the feeling of happiness, satisfaction, health, and psychological well-being in the life of every individual. Leisure is connected to a relative freedom. The individual feels free from pressure or limitations, has a feeling of positive impact, and is motivated by an internal enthusiasm. Leisure allows one to discover and use one's abilities as well. The term leisure has been used since the 1940s in American society. Over time, its meaning has been established. The term leisure means the ways to bring balance to one's life. This covers not only the possibility of relaxing, personal development, cultural and family stability, and interaction, but also the possibility of escape, originality, complexity, adventure, excitement, and fantasy. ${ }^{42}$

Stebbins, one of the authors dealing with leisure time and free time issue, ${ }^{43}$ offers the following definitions of the two terms. In his opinion, leisure covers optional activities. Either these activities or the way to their realisation bring satisfaction. One can use one's skills or ideas to do them and be successful. All of this takes place during the time sequence called free time. Free time, on the other hand, is a time away from unpleasant duties. It has been built on pleasant engagements (to be pleased, served, or cured) since the time of homo otiosus - leisure man. ${ }^{4}$

One could assume that the term free time covers a broader part of space and time than leisure. Free time is seen as a time without duties, as a time available for the individual's choice. Whether one uses this time for leisure or for any other purpose depends on one's free choice. Leisure then can become a part of free time. There is a question, though, whether one can fill his free time by something other than leisure? Or is it true that every free time activity is leisure? And is it also true that all leisure is free time? Or can one say that leisure is based on the quality of activities (and, therefore, it can be spent wherever and whenever - and that includes one's free time) while free time has its clear limits (given by the fact that it takes place out of work and duties, and it is a space for meaningful use)? If the last assumption is true, then it would be hard to claim that free time is a wider term than leisure. Also, it would be even harder to compare their width and scale as they are based on different paradigms. Leisure is defined by the quality of an activity whereas free time is based on the quality of time.

Stebbins ${ }^{45}$ adds the idea that sometimes the terms free time and leisure can be exchanged. One can be bored during one's free time, which is a consequence of inactivity or uninteresting activity. The same situation can happen at work or during the fulfilment of other duties. If boredom is considered a negative state of mind, then one can argue that such a situation is not leisure as leisure is characterised by a positive attitude. Such an attitude consists of (besides other things) opinions, positive expectations, and memories concerning the activities and situations experienced. However, the individual's expectations can be unrealistic, and he then becomes bored. Then he can modify the situation and change it into something quite different from leisure. This whole process can take place within the free time framework. As one can see, then, it perfectly illustrates the fact that free time can cover a wider part of life than leisure (as leisure is positioned within the extent of free time). Stebbins ${ }^{46}$ distinguishes between serious leisure and casual leisure, however, if one connects these

42 Cf. EDGINTON, DIESER and DEGRAAF, Leisure..., pp. 31-38.

43 Cf. STEBBINS, New Directions...; cf. Robert. A. STEBBINS, Serious Leisure. A Perspective for Our Time, New Brunswick: Transaction Publishers, 2007, pp. 1-5.

44 Leisure man is a person whose wealth and/or social status allows him to deal only with pleasant social, cultural and sport events, or some amusement. These activities prevail over his working duties. Originally, this term characterises a man who is financially independent, and can spend his time focusing on any pleasant activity. This takes place during the sequence of time when other people have to work. 
two approaches then leisure is a source of informal experiments, accidental discoveries, and spontaneous inventions. Thus, leisure is the main source of happiness. It is further connected to the permanent usefulness which is associated with self-realisation, self-enrichment, and self-evaluation strengthening - thus, it is associated with the strengthening of identity ${ }^{47}$ and with the strengthening and development of activities and strategies for the desired personal and social status. Leisure is also connected with social capital production, an increase of solidarity between the individual's confirmation of independence, and between the individual and social group (this is enabled by the network of relationships which form a base for reciprocity and reciprocal help in case of need). ${ }^{48}$

Havighurst ${ }^{49}$ and Kaplan ${ }^{50}$ connect leisure mainly with participation in the life of society both in the wider and narrower sense (which includes local communities, education, self-development, and permanent profit). Havighurst ${ }^{51}$ further connects leisure with enough opportunities for interesting feelings and creative personal expression. In his view, it also accentuates the regular and routine creation of life activities. Leisure should be a source of self-respect, and respect to others. Kaplan $^{52}$ indicates the requirement of a relationship towards society through the consciousness forming. The idea is to 'belong to something somehow'. He thinks that leisure should be useful to an individual as well as to society (leisure lifestyle). He also connects leisure with the development of one's individuality, and with bringing various individual functions into balance. Leisure supports these functions by bringing positive experiences and inhibiting creative forces. He does not forget about the balancing function. In his opinion, leisure can put in balance the pressure coming from work or everyday rush. Leisure is also positively connected to education, to the process of gaining new information, and it also significantly affects one's life direction and its formation.

Leisure is associated with the creative and active experiencing of leisure time. According to some authors (e.g., Rojka), the passive or consumer-like use of leisure time cannot even be considered leisure. ${ }^{53}$

One can assume that leisure means for different people different things. These various meanings have induced the creation of several concepts: leisure as time, an activity, a state of mind, a quality of activities, a social construct, a social instrument, the anti-utilitarian concept, and a part of the holistic process. ${ }^{54}$

If one then considers leisure time a residual category (as presented in Chapter 2.1 where this concept follows mainly sociology in Weber's, Parson's or, currently, in Robert's ${ }^{55}$ view), it is then leisure time in the sense of free time. Opposite this, there is the positive definition of leisure time (mentioned in Chapter 2.1) which deals (foremost) with the creation of space - free time. But, even here, it is expected that free time will be used for leisure (that is, for activities which bring positive personal development, and thus affect one's life and lifestyle). Kaplánek ${ }^{56}$ states that while it is possible to be bored during one's free time, it is impossible to perceive leisure in the same way.

\footnotetext{
Cf. Shaun BEST, Leisure Studies: Themes \& Perspectives, London: SAGE Publications, 2010, pp. 177-258.

Cf. STEBBINS, New Directions..., pp. 177-179.

49 Cf. Robert J. HAVIGHURST, Employment, retirement and education in the mature years, in: Guglielmo WEBER, Aging and retirement, Gaingswill, 1955.

50 Cf. Max KAPLAN, Leisure in America, New York: Willey, 1960, p. 76.

51 Cf. HAVIGHURST, Employment...

52 CF. KAPLAN, Leisure..., p. 76.

53 Cf. Chris ROJEK, Leisure and Culture, New York: Palgrave Macmillan, 2000; cf. Chris ROJEK, Leisure Theory: Principles and Practice, New York: Palgrave, 2005.

54 Cf. EDGINTON, DIESER and DEGRAAF, Leisure..., pp. 38-44.

55 Cf. Ken ROBERTS, Leisure Industries, New York: Palgrave Macmillan, 2004

56 Cf. KAPLÁNEK, Volný čas..., p. 29.
} 
How then (in the context of this chapter) to think about weisure? In comparison with free time (which has clearly defined limits), weisure makes the limits loose. In this way, it erodes (or even eliminates) the concept of leisure time (Chapter 1). What about the relationship between weisure and leisure? It was said that leisure does not have to take place within free time, and it is defined by the quality of activities. If one views weisure within the framework of positive personal development in the context of both the person himself and society (as described in this chapter), then weisure does not contain the quality of leisure. It is more or less a bad habit which consequently leads to the development of an unhealthy lifestyle (Chapters 3 and 4). And even if the phenomenon weisure is created from leisure and work (as described in Chapter 1), it (in fact) ruins the essence of both these bases. ${ }^{57}$

\section{Weisure as a Fulfilment of the Ideal Leisure Time Lifestyle?}

While in the past man worked and climbed up an imaginary career ladder ${ }^{58}$ to gain more time for home, family, and friends, today it is the other way around, that is, the better the job position, the more time one spends at one's job. ${ }^{59}$ While Dumazedier ${ }^{60}$ spoke about a society of leisure time, and considered it a vision of our future (that is, modern technology could enable the shortening of work time and, at the same time, the lengthening of time devoted to oneself, family, and hobbies), it is the exact opposite nowadays. Modern technologies are tools which enable people to work outside the office, even during their time off work. The effect is that people work more. Of course, the character of work has changed. A part of the population enjoys work (or at least some of its aspects), and some people see their job as a hobby. ${ }^{61}$ Also, society has changed due to the process of personalisation. It is less influenced by external determination. The behaviour of individuals is the result of an unconscious searching for oneself, for one's true self. ${ }^{62}$

It looks as if Marx's theory of alienation of work ${ }^{63}$ or Habermas's compensation theory ${ }^{64}$ have been losing their impact on current society. Leisure time is now perceived more in accordance with Dumazedier ${ }^{65}$ who connects leisure time with inactivity in the area of social engagements, work, and needs (in the area of maintenance and development of one's life). In contrast to the residual theory of leisure time (mentioned in Chapter 2.1), he sees this time as a sum of activities which are entered into with positive anticipation, and bring pleasant experiences and satisfaction. He considers one's choice to decide freely the basic attribute of leisure time.

Sue, ${ }^{66}$ a French sociologist dealing with leisure time, adds to the abovementioned view the social function. He associates this function with the socialisation process in different social environments, which leads to the social recognition of an individual. Whether leisure time includes this function even in the postmodern (or hypermodern) time, and what scope or what form socialisation (as a function of leisure time) can have or fulfil, are questions for discussion. It is debatable especially if one acknowledges the fact that (according to Lipovetsky):

57 Cf. Ulrich BECK, Risikogesellschaft (Auf dem Weg in eine andere Moderne), Frankfurt am Main: Suhrkamp Verlag, 1986, pp. 113-250.

58 Cf. Steven J. OVERMAN, The Protestant Ethic and the Spirit of Sport. How Calvinism and Capitalism Shaped America's Games, Macon, GA: Mercer University Press, 2011, pp. 17-41.

59 Cf. CONLEY, Elsewhere..., pp. 141-155.

60 Cf. Joffre DUMAZEDIER, La révolution culturelle du temps libre (1968-1988), Paris: Méridiens Klincksieck, 1988 , pp. 58-175.

61 Cf. EDGINTON, DIESER and DEGRAAF, Leisure..., pp. 29-41; cf. LEE, Living...

62 Cf. LIPOVETSKY, Lére du vide..., p. 76; cf. LIPOVETSKY, L'empire..., p. 54.

63 Cf. MARX, Das Kapital..., pp. 873-874.

64 Cf. HABERMAS, The structural...

65 Cf. Joffre DUMAZEDIER, Vers une civilisation du loisir?, Paris: Editions du Seuil, 1962, pp. 46-168.

66 Cf. Roger SUE, Le loisir, Paris: Presses universitaires, 1993, pp. 31-52. 
The process of personalisation leads to the end of socialisation which is based on discipline. After authoritative and mechanical drill comes the homeopathic and cybernetic way of socialisation, after commanding management comes the customised optional programming. The process of personalisation puts forward personal realisation and respect for subjective peculiarity and unique individuality as a basic value. The right to be oneself, and to enjoy oneself as much as possible as inseparable from society which has made one's freedom the basic value. This establishment is the furthest sign of individualistic ideology. Social and individual behaviour is not motivated by the effort to reach universality anymore. The goal is to find one's own identity. ${ }^{67}$

In the citations of our authors (Dumazedier and Sue) one can notice that even if they give leisure time its own value (which does not depend on work but rather on the meaning of leisure time activities in the context of life as a whole; compare with Chapter 2.1), they still consider leisure time a time sequence with a clear detachment from work. As stated in Chapter 1, though, the border is becoming loose in postmodern society. In the subjective mind of some people, this border does not even exist. Whereas in the past people worked hard in order to be able to work less in the future (or to build such a future without work for their children), today there is a different rule. The more one makes the more one works. Whereas in the past a larger salary brought freedom, ${ }^{68}$ nowadays the more people earn the more pressure they feel. ${ }^{69}$

To be 'on' twenty-four hours a day in the week is becoming the 'new normal'. If the relationship between work and private life is changing, the relationship between work and leisure time (and between work and life itself) is changing as well. The borders have been erased. So how is it possible then to find life balance (as mentioned by Pieper ${ }^{70}$ in Chapter 2)? Hannah Inam ${ }^{71}$ offers a solution: to stop looking for balance and start to think about how to make oneself full of energy and creative in life - how to live with passion and to be able to contribute (that is, to bring some kind of contribution). This appeal reminds one of Horst Opaschowski ${ }^{72}$ and his thoughts. He was there when the conception of leisure time pedagogy (Freizeitpädagogik) was born. Its aim was to integrate the areas of work and leisure time into the unity of one human life, and to overcome the gap between work and leisure time (between the public and private spheres, as mentioned in Chapter 1) as described by Habermas. ${ }^{73}$ Man should make himself better at organising his entire time freely and, at the same time, responsibly. Such an approach then can allow a person to use his time sequences according to his will, and for the best interest of everyone (including the person himself). ${ }^{74}$

According to Inam ${ }^{75}$ man should (when looking for internal balance) primarily look into his inner soul (and find inner freedom) without the expectation of some external initiative (or external circumstances). Life balance cannot be the aim of human life, that is, the reason why one lives, but it should be present in life as its prerequisite. ${ }^{76}$ It is as if one goes back to the concept of contemplative life (Chapter 2) which could have been met in the period of Greek philosophy with its emphasis on life balance. Greek philosophy was based on two spheres - an active life

67 LIPOVETSKY, L’ére du vide..., p. 10.

68 Cf. HABERMAS, The structural..., pp. 141-180.

69 Cf. CONLEY, Elsewhere..., pp. 154-168.

70 Cf. PIEPER, Muße und Kult..., pp. 43-50.

71 Cf. () Henna INAM, Forget work life balance: seven paradigm shifts for the new 24/7 normal. Forbes.com. October 7, 2013. Retrieved from https://www.forbes.com/sites/hennainam/2013/10/07/forget-work-life-balance-seven-paradigm-shifts-for-the-new-247-normal/.

72 Cf. OPASCHOWSKI, Pädagogik der Freizeit..., pp. 28-56; cf. Horst OPASCHOWSKI, Paedagogik und Didaktik der Freizeit, Opladen: Leske und Budrich, 1987, pp. 32-64; cf. OPASCHOWSKI, Pädagogik der freien Lebenszeit..., pp. 22-43.

73 Cf. HABERMAS, The structural..., pp. 141-180.

74 Cf. OPASCHOWSKI, Pädagogik der freien Lebenszeit..., pp. 22-43.

75 Cf. INAM, Forget...

76 Cf. INAM, Forget... 
(including the worries of everyday life) and a contemplative life (including the process of looking for the truth without the pressure of everyday life) ${ }^{77}$ Nevertheless, according to Inam, ${ }^{78}$ balance should not be brought into life through contemplation. The right way leads through relaxation and amusement, which are presented as a part of the working process. The current living person should, on the contrary to a time of contemplation (when one had to cut off the worries of everyday life in order to be able to focus on looking at things perceived by the senses), go deeply into an activity, be swallowed up and carried away by the flow of the creative process. Contemplation was the prerequisite for future life, and flow is the process of making the future present. ${ }^{79}$ Amusement should be the way how to eliminate things which could disturb or prevent the state of being swallowed up. While contemplation should provide space for reflection and organisation of values which lead to self-understanding and to the discovery of one's own value, flow is the prerequisite for life characterised by the complete and deep involvement in activities (the author calls it 'absorption'). ${ }^{80}$ While contemplation is the way how to free oneself from the production or consumption as the only purpose of life, ${ }^{81}$ and the way towards freedom and life balance, flow is the way how to become one with work - to stop being workforce ${ }^{82}$ and become the work itself. The life of modern people was shattered into two spheres - work and leisure time (Chapter 2.1), which should be (according to Opaschowski ${ }^{83}$ ) integrated into one piece. The lifestyle of current people (i.e., the weisure lifestyle) shows some integration but its result is the reduction of life to work (even to just supposed work) instead of living one's life as a whole. ${ }^{84}$ In this sense, Conley ${ }^{85}$ adds that people spend many hours at work, therefore, they have no time for other activities (that is, for the activities which would be normally done in one's leisure time). On the other hand, they spend many hours at work due to the fact that they do not concentrate on work itself. They deal with many other things around, which is, to a great extent, the consequence of individualism and its deepening. Individualism prefers self-control to the traditional forms of conformity with standard. Unfortunately, it is accompanied by a weak will and a lack of commitment. The result is that an individual is not able to postpone some activities because his life is focused on the current moment. ${ }^{86}$ Some people even believe that this is the only way of doing things. On the contrary, they think that this is a better way of using their time. The fact is that modern technologies do most of the work for them. In this way, there is some time which does not have to be wasted, and can be used for other activities, either for fun or other work. People do not realise, though, that they do not do any of these activities fully. They even think that they are very successful as they can do more activities in one moment (multitasking).$^{87}$ At the end, it is not clear if people have fun or if they work. The problem is that they do not reach the goal of the activity itself in neither case. ${ }^{88}$ According to Lipovetsky ${ }^{89}$ this culture is hyperactive. It is aimed at efficiency, which has no concrete sense or goal, and it is directed at things that are here and now. In hypermodern society,

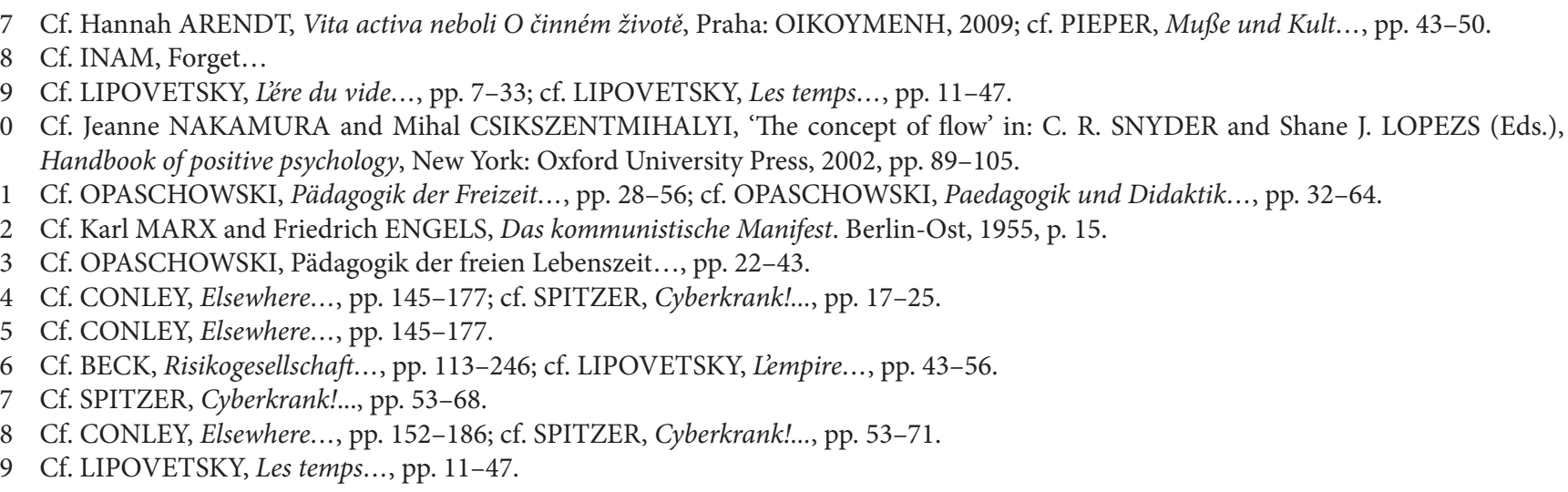


man has the feeling of a lack of time, and thus the time paradox arises: the quicker one is, the less time one has. Consequently, weisure cannot be considered the fulfilment of the leisure lifestyle. On the contrary, these two lifestyles are in contradiction in many ways.

\section{The Instrumentalisation of Leisure Time}

Weisure is not a typical phenomenon just for adults. Even children show the sign of weisure or of the instrumentalised leisure time (as pointed out in Chapter 2.2, it is leisure not free time as the borders between work and leisure time are disappearing). Whereas children played in the past, now they are socialising with their peers. Previously they played with clay, now they improve their manual skills through 3D tools. In the past, they kicked a ball, now they polish their physical skills. Previously they played football, and now they learn to function in a system based on rules, with the help of institutionalised adult authorities (trainer, coach, or teacher). It may seem that there is no difference between these ways of doing things, that they are just the same but with different names. In fact, these could really be the same activities with just different names but often they are not. The change comes not just with the children's activities. There is significant difference in the children's thinking and reactions. Often, one cannot even speak about leisure time as this space is disappearing. Instead, there is an instrumentalised leisure - weisure. ${ }^{90}$

It is not the first time in history when one has met the instrumentalisation of leisure time. In 1892, a conference took place in Germany. It was organised by Berliner Centralstelle für Arbeiter-Wohlfahrtseinrichtungen, and was focused, among other topics, on the question of 'how to use leisure time efficiently'. Leisure time was a new area of life (as shown in Chapter 2) which was raising questions, or even worries in the countries strongly influenced by the Protestant ethic. ${ }^{91}$ The danger, connected with the time when one can do whatever one wants (including the option of doing nothing useful or efficient), led to leisure time with a pedagogical character. This approach can be observed even later, in the practice of totalitarian regimes of twentieth century - Nazism and communism.

One can meet a call for the 'meaningful spending of leisure time' (as an aim of leisure time pedagogy) even nowadays. ${ }^{92}$ This is, nevertheless, nothing other than the instrumentalisation of leisure time. The majority of children's time is organised by adults. ${ }^{93}$ In this way, their time partly or completely loses the character of leisure time and becomes a kind of obligation. If there is some time left, children often spend it by playing computer games ${ }^{94}$ which prepare them for their future working life. These games teach them to earn money, buy and sell things, increase their capital, plant seeds, make raw material, and virtually feed their two-dimensional pets (the most popular and widely spread is Minecraft, ${ }^{95}$ which even offers interconnection with LEGO ${ }^{96}$ building kits). This category includes even classic board games (made specifically for this practical educational purpose).${ }^{97}$ If one leaves out the possible negative impact of PC games and online technologies on

90 Cf. CONLEY, Elsewhere..., pp. 144-152.

91 Cf. Max WEBER, Die protestanische Ethik und der Geist des Kapitalismus, München: Verlag C.H.Beck, 2004.

92 Cf. OPASCHOWSKI, Pädagogik der freien Lebenszeit..., pp. 28-56; cf. KAPLÁNEK, Pedagogika...; cf. KAPLÁNEK, Volný čas..., pp. 23-30

93 Cf. () Peter GRAY, How we deprive children of the physical activity they need. Psychology Today. Posted 29 $9^{\text {th }}$ June 2018, available at: https://www.psychologytoday.com/us/blog/freedom-learn/201806/how-we-deprive-children-the-physical-activity-they-need.

94 Cf. (c) Petr SAK, Promèny volného času a zaostávání pedagogiky, 2006, available at: http://www.insoma.cz/index. php?id=1\&n=1\&d_1=paper\&d_2=2006_06a.

95 Cf. @ Microsoft. Minecraft (online), 2019, available at: https://minecraft.net/en-us.

96 Cf. () LEGO Group. LEGO (online), 2018, available at: https://www.lego.com/cs-cz/themes/minecraft.

97 Cf. @ Dětský podnikatelský klub (online), 2019, available at: http://www.detskypodnikatelskyklub.cz/nase-hry. 
the child's development, ${ }^{98}$ it is still a connection of work and game. Work resembles home (and home is similar to work) not just for adults but for their children as well. The difference between the private and public sphere is unrecognisable, unclear. ${ }^{99}$ Children are not only affected by the cyber way of socialisation, but they are variably programmed in accordance with demand ${ }^{100}$ and formed in conformity with the weisure lifestyle.

Education within leisure time belongs to informal education, which complements formal education. In the Czech Republic, since 2012, formal education has been functioning in accordance with the Framework Education Programme. ${ }^{101}$ This programme introduces the term 'key competences' (in the European context, this term had appeared in connection with education in 1990s). It is a set of knowledge, skills, attitudes, and values which should be acquired by the individual. Then, these qualities should be used as a base for further development in personal and professional life. If one acquires these key competences, one should be able to successfully join society and, at the same time, the functioning, economic efficiency, and competitiveness of society as a whole should be assured. ${ }^{102}$ Even if the process of acquiring should not take place at the level of material values production only (this means a successful position in the market and in the working process), it is a prior goal. If the acquiring of key competences should lead towards an understanding of one's own being (of one's self), perceiving one's own life as a whole, and the understanding of one's life in relation to other people and society, ${ }^{103}$ then this process would contain value education mainly (this will be dealt with in Chapter 5). The concept of key competences contains value education marginally only. ${ }^{104}$

The change of leisure time (either in the sense of free time or leisure) into a mere tool (of the pedagogical evaluation of leisure time, risk prevention from actual risks or imaginary ones, manipulation, or the market ${ }^{105}$ ) and the aiming of education at the meaningful (or effective) use of leisure time (Chapter 2.1) become, in many aspects, a base for the development of weisure lifestyle.

\section{Weisure as a Challenge for Leisure Time Pedagogy}

Leisure time pedagogy includes not only education in leisure time but also education for leisure time, and education by leisure time. One can speak about three dimensions of this education: the first is the education itself (which takes into account specific conditions deriving from the relatively free decision making of an individual in a particular time sequence in his life), the second is the leisure time (its valuable usage derives from one's motivation and developed competences), and the third is the educational means. ${ }^{106}$ If one considers the purpose of leisure time pedagogy in

98 Cf. Manfred SPITZER, Demencia digital, Ediciones B, 2013, pp. 119-201; cf. SPITZER, Cyberkrank!...; cf. ( ) Peter GRAY, Benefits of play revealed in research on video gaming. Psychology Today. Posted $27^{\text {th }}$ March 2018, available at: https://www.psychologytoday.com/us/ blog/freedom-learn/201803/benefits-play-revealed-in-research-video-gaming.

99 Cf. CONLEY, Elsewhere..., pp. 144-152.

100 Cf. LIPOVETSKY, Lére du vide..., 12-32.

101 Cf. @ Metodický portál RVP, Rámcový vzdělávací program pro základní vzdělávání (online). Praha: VÚP, 2007, available at: http://www. vuppraha.rvp.cz/wp-content/uploads/2009/12/RVPZV-pomucka-ucitelum.pdf, cited $8^{\text {th }}$ March 2019.

102 Cf. (C) Communication department of the European Commission, Lisabonská strategie (online), available at: www.europa.eu, cited $8^{\text {th }}$ March 2019.

103 Cf. () UNESCO Digital Library, Learning: the treasure within. Report to UNESCO of the International Commission on education for the twenty-first century (online), available at: https://unesdoc.unesco.org/ark:/48223/pf0000109590, cited $8^{\text {th }}$ March 2019.

104 Cf. Martina KOČEROVÁ and Petr BAUMAN, Rozvoj kritického a tvořivého myšlení v prostoru volného času, in: Kritické a tvořivé myšlení: není to málo?, ed. Petr BAUMAN, České Budějovice: TF JU, Centrum filozofie pro děti, 2013, pp. 168-185.

105 Cf. KAPLÁNEK, Volný čas..., pp. 24-93.

106 Cf. Petr BAUMAN, Východiska pedagogiky volného času v perspektivě soudobých edukačních koncepcí, in: Volný čas a jeho význam ve výchově, ed. Michal KAPLÁNEK, Praha: Portál, 2017, pp. 51-60. 
connection with the phenomenon weisure (which is characterised by the blurring or even erasing of borders between working time and leisure time), then it is necessary to ask oneself whether these three dimensions are still up-to-date.

In order to answer this question, one has to select the target group. Leisure time pedagogy (in the current perception) does not focus on children and youth only (as seen in the narrower concept of leisure time pedagogy which builds on afterschool education) but on adults or seniors as well. Nevertheless, if one takes into account the psychological development in Erikson's view, ${ }^{107}$ then personal maturity comes with adulthood, and the deep forming of personality (which takes place during childhood and adolescence) diminishes. Of course, an individual is capable of deep changes even during adulthood. Such changes, though, depend on his personal decision as the significance of educational influence of other adult people diminishes, and the changes are more demanding on time than in the period of childhood.

On the contrary, childhood and adolescence are the periods of maturity and development where the personality of an individual is not yet formed. These periods are characterised by experimenting and looking for meanings. And even if personal decisions play a significant role at this age, other people (parents and pedagogues mainly) and social environment have a major influence as well. ${ }^{108}$ It can be assumed that the behavioural patterns, value orientation, and skills acquired in childhood become the base for the thinking, considering, and acting of an individual in adulthood. If, then, the base for leisure time instrumentalisation is built during childhood (as shown in Chapter 4), an individual will keep this approach to leisure time and bring it into his adulthood with great probability. Conversely, if an individual develops that kind of thinking which is aimed at understanding leisure time and its value for quality of life, the preventive base can be built against the development of weisure lifestyle in childhood and adulthood as well. Considering the stated facts, the primary target group for leisure time pedagogy (in the case of preventive actions against the weisure lifestyle development) should be children and the youth.

The weisure lifestyle is accompanied by the blurring of borders. The distinction between work and leisure time, between working activities and fun, is not clear. Due to the fact that this trend cannot be separated from the developmental stage of society, weisure is connected with the lowering of significance (or even the loss of significance) of referential frameworks which represent signposts in the process of orientation in life (Chapter 1). Individualisation and personalisation are accompanied by the weakening of will and the state of being unbound that brings the absence of goals and sense, ${ }^{109}$ the weakening of the ability to decide, and the inability to grasp one's freedom responsibly. One focuses primarily on current moments. This is emphasised in the case of children who are, according to psychological development, in the phase of concrete thinking. During the development of abstract thinking (in the case of youth), ${ }^{110}$ awareness of the future comes. This future is, however, perceived as unknown, unsure, and therefore unwanted. The consequence is escape into the present moment, a strong attachment to one's childhood, and the denial of adulthood. ${ }^{111}$ Weisure is then the consequence of modern technology usage. Since early childhood,

107 Cf. Erik H. ERIKSON, The life cycle completed, New York: W. W. Norton \& Company, 1998.

108 Cf. Jan ČÁP and Jiří MAREŠ, Psychologie pro učitele, Praha: Portál, 2001; cf. Jean PIAGET and Bärber INHELDER, The psychology of the child, New York: Basic Books, 2008; cf. Lev S. VYGOTSKY, Concrete human psychology, Soviet Psychology 2/1989, pp. 53-77.

109 Cf. LIPOVETSKY, Les temps..., pp. 11-47.

110 Cf. ERIKSON, The life cycle..., pp. 55-82.

111 Cf. Benjamin R. BARBER, The global infantilization: how we become more and more 'kidults' without noting loss of freedom in society, Der Tagesspiegel, September 9, 2001; cf. Benjamin R. BARBER, Consumed: how markets corrupt children, infantilise adults and swallow citizens whole, New York: W. W. Norton, 2007; cf. () Martina KOČEROVÁ, Post-Adolescent Society as a Challenge for Education, Pedagogická orientace 4/2017, available at: https://doi.org/10.5817/PedOr2017-4-520, pp. 520-539. 
children are exposed to the impact of modern technologies, and this process influences the process of socialisation significantly. The socialisation of children (which should take place in various social groups) is disrupted, and sometimes even replaced by cyber socialisation (Chapter 3 ). ${ }^{112}$ Leisure time pedagogy should, in the case of children and youth, focus on: (1) the development of leisure time competences, (2) value education, (3) the development of critical thinking, and (4) socialisation. The development of leisure time competences is not connected with leisure time only. It is connected with time in general. It is a complex of abilities, skills, and characteristics which enable an individual to manage his time freely and responsibly. The key factor is the grasp of one's own freedom. The development of one's leisure time competences helps to build a base for free life appreciation, and for decision making. These abilities should be nourished by conscience and critical thinking (considering one's own good as well as the common good). Leisure time competences enable an individual to reflect his needs, to understand himself critically, and to consider social circumstances. ${ }^{113}$

The key values (in the process of reflection and critical thinking) create the foundation for decision-making based on criteria. The formation of the system of values creates the base for attitudes and decision-making in one's life during adulthood. This is connected with the ability to take responsibility for oneself, one's own decisions, one's own life. ${ }^{114}$ Value education is not about the mediation of ready-made value knowledge. Values should be understood as an instrument used for influencing the activities, motivation, and life planning of an individual. ${ }^{115}$ Value education and critical thinking are connected through reflection which leads to the overcoming and transformation of unclear issues, doubts, and conflicts. The result should be a certain state which enables one to find life balance. ${ }^{116}$ It is then not only about value education (which enables one to find sense for values) but also about the education which leads towards evaluation and a conscious reflection of one's own judgements. ${ }^{117}$

Leisure time is accompanied by the formation of informal relationships. These then are the starting point of informal social groups (as stated in Chapter 2.2). Some authors connect leisure with participation in society and with a feeling of solidarity. ${ }^{118}$ These groups are formed on the basis of common interest. An individual is not put into them; he wants to belong there. Leisure time is more suitable for the formation of relationships than, for example, a formal group. A child is put into a school class (a formal group) without any possible impact on this act. In informal groups, the process of development of social competences can be carried out more easily. We speak precisely about these social competences which enable an individual to be in contact with society, to build relationships, and to break down social barriers. In such a way, the tendency to escape from society and the privatisation of interests are put into balance. Social competence is closely associated with communicative competence. The latter includes the ability to express oneself, to understand, to create relationships, and to behave appropriately in society. This competence, thus, prevents social isolation, and helps the process of socialisation. ${ }^{119}$

112 Cf. SUE, Le loisir..., pp. 31-52; cf. SPITZER, Demencia..., pp. 119-201.

113 Cf. OPASCHOWSKI, Pädagogik der freien Lebenszeit...; cf. PIEPER, Muße und Kult...

114 Cf. ERIKSON, The life..

115 Cf. Naděžda PELCOVÁ, Hodnotová výchova a výchova k hodnocení, Pedagogika 10/2013, pp. 285-300.

116 Cf. John DEWEY, How we think. A restatement of the relation of reflective thinking to the educative process, Boston: D.C., 1933.

117 Cf. PELCOVÁ, Hodnotová...

118 Cf. HAVIGHURST, Employment...; cf. KAPLAN, Leisure...; cf. Robert A. STEBBINS, Leisure and Positive Psychology: Linking Activities with Positiveness, London: Palgrave Macmillan, 2015.

119 Cf. KAPLÁNEK, Volný čas... 
The essence of leisure time is freedom. Thus, the ongoing processes can be managed (or managed in cooperation) by the participants themselves on the basis of their own decisions. During leisure time, self-control can prevail over control. One can make discoveries, unveil the sense and the essence of things (Chapter 2), and learn from mistakes as the ongoing processes do not have to be primarily aimed at results (or these results do not have to be reached within some given time period) in one's leisure time. A child can go deeply into the process, explore various solutions, experiment, do nothing, or even choose a way which does not lead to the finish line in order to gain experience, or to test the mediated theoretical knowledge (the development of cultural and creative competence). He can learn to set goals, to decide, and to take responsibility for his own decision (to the extent which is accurate to the current psychological development). In this way, he can prepare himself for taking responsibility later in adulthood. ${ }^{120}$

As stated at the beginning of this chapter, two major groups form children's lifestyles at an early age: parents and pedagogical workers (in the view of this article, these are mainly leisure time pedagogues). They are the ones who influence the form of children's leisure time the most. Therefore, leisure time pedagogy should be aimed at them as well. Leisure time pedagogy should, in accordance with its tasks, help parents decide about their children's leisure time (i.e., about the way how children spend this time). The goal is to prevent the instrumentalisation of leisure time (see Chapter 4) as much as possible. Leisure time pedagogy should focus mainly on book publishing in this area. Among other activities, there should be seminars and lectures for parents about how to spend leisure time, and about value education. The latter is quite significant as it leads towards a critical understanding of oneself and a reflection of social context. ${ }^{121}$

Focusing on leisure time pedagogues, importance should be given to their professional training. This, however, cannot be separated from their personal growth. In the Czech Republic, their training does not have adequate attention, and the social status of leisure time pedagogues is not very high (it is rather low, which can be seen in law documents containing the professional training of leisure time pedagogues ${ }^{122}$ ). The consequence of this state is that one can meet many pedagogues who are primarily focused on the planning and realisation of the programme offered. There are considerably fewer of those, though, who pay attention to the development of abilities, and to the acquirement of skills which enable a child to realise his personality not only in the context of his society and culture but in overall life context as well. ${ }^{123}$ Among leisure time pedagogues one can find more of those who accent the adequacy of the journey, and the attractiveness of activities rather than creating space for questions, considering dilemmas, confronting oneself in various situations, looking for solutions, deciding, and accepting responsibility.

If it should be mostly about value education (as stated above in connection with children and youth), it cannot be the mere realisation of activities in spite of their attractiveness, enjoyability, or their meaningful character. If one changes the educational influence in leisure time for the fulfilment of leisure time with activities, then the result could be the instrumentalisation of leisure time and the development of the weisure lifestyle. A child is taught to consume leisure time activities, to amuse himself, and to choose selectively according to his current mood or fashion. Such an

120 Cf. Peter GRAY, Play as a foundation for hunter-gatherer social existence, American Journal of Play, Spring 1/2009, pp. 476-522; cf. David F. LANCY, Teaching: natural or cultural?, in: Evolutionary perspectives on child development and education,ed. David C. GEARY and Daniel B. BERCH, New York: Springer, 2016, pp. 33-65.

121 Cf. OPASCHOWSKI, Pädagogik der freien Lebenszeit..

122 Cf. (C) Zákon č. 563/2004 Sb., o pedagogických pracovnících a o změně některých zákonů, available at: http://www.msmt.cz/file/38850/, cited $8^{\text {th }}$ March 2019; cf. Vyhláška č. 317/2005, o dalším vzdělávání pedagogických pracovníků, akreditační komisi a kariérním systému pedagogických pracovnikư, available at: http://www.msmt.cz/file/38840/, cited $8^{\text {th }}$ March 2019.

123 Cf. @ UNESCO Digital Library, Learning... 
approach takes place instead of learning how to deal with one's freedom, how to be responsible, how to improve one's endurance, and how to find one's meaning of life.

Value education and the associated development of leisure time competences, critical thinking, and reflective practice ${ }^{124}$ create a demanding situation for pedagogues, who have to manage themselves in the spirit of these qualities. They should be focused on reflection of the current situation with an emphasis on the developing postmodern lifestyle rather than on creating a large number of leisure time activities as these activities do not ensure value education (often they are not valuable at all). Primarily, leisure time education should not be aimed at creating a multiple number of activities (or piling up experiences). Its main goal is to teach individuals to think, consider, and reflect. The activities should be a tool, or a suitable environment for the process of thinking about oneself (or sense of life). This process should be followed by the formation of value orientation and critical thinking.

\section{Conclusion}

Weisure is connected with the process of blurring or even erasing the borders between work and leisure time (see Chapter 1), and with the current lifestyle in western society. Whether this society is in the latest phase of modernity, ${ }^{125}$ or postmodernity, ${ }^{126}$ or even hypermodernity, ${ }^{127}$ is a subject of further discussions which are beyond the framework of this article. Whichever name one uses for our society, the ongoing changes are undeniable. While in Lipovetsky's ${ }^{128}$ modern times an individual was clearly raised to be disciplined, to behave in a normalised and standardised way, the current times are characterised by individualisation and personalisation. Human behaviour is not led by tradition. It is rather defined by the possibility of private choice. This should be as wide as possible. The traditional ways of normalisation are losing their influence. The emphasis is on freedom and self-control. On the other hand, personalisation is accompanied by weak will and therefore by low internal motivation (Chapter 1).

What role can leisure time pedagogy play in our society where leisure time is mixed with work? Does it still have some role or sense? Whether one focuses on leisure time pedagogy in the form of afterschool education (as developed mainly in socialist countries), or in the German view (i.e., as free activity with children and youth), both forms clearly define the term leisure time. The goal of leisure time pedagogy - to teach children and youth how to spend their leisure time in some meaningful way (Chapter 2.1) - was also clearly defined in both cases. Regardless of the fact whether the reason was a real interest in children's personality development, ideological education, or the prevention of social-pathological problems, this approach has gradually led towards the instrumentalisation of leisure time, and towards the pedagogical forming of leisure time (Chapter 4). Giving the current development of society, the emphasis on the meaningful spending of leisure time seems outdated (Chapter 5). Current society brings new challenges even for leisure time pedagogy. Some even question the sense of leisure time pedagogy at times of weisure lifestyle where there are no clear borders of one's leisure time.

Weisure lifestyle has developed mainly in western countries. If one focuses on leisure time edu-

124 Cf. DEWEY, How we think..

125 Cf. Zygmunt BAUMAN, The liquid modernity, Cambridge: Polity Press, 2000.

126 Cf. Jean-Françis LYOTARD, Toward the postmodern, New York: Humanity Books, 1998; cf. Jean BAUDRILLARD, The consumer society: myths and structures, London: Sage Publications, 1998.

127 Cf. LIPOVETSKY, Les temps...

128 Cf. LIPOVETSKY, Lére du vide...; cf. LIPOVETSKY, Les temps... 
cation of these countries, it is possible to find that this type of education has not been improved, developed, or put into practice significantly in recent times. While in the past in the United States, the topics of leisure time education was an important part of the discourse about the education conception, nowadays this aspect is not a very important part of documents concerning American educational politics. ${ }^{129} \mathrm{~A}$ similar situation is in Germany. In the twentieth century, a major subject called Leisure Time Pedagogy was being developed. Then, after discussions whether it is appropriate or inappropriate to add a pedagogical character to the time of freedom, the educational character has been diminishing (currently, it has been mainly the pedagogical research of leisure time).$^{130}$ Has leisure time pedagogy lost its significance?

The situation in the Czech Republic is somewhat different. Leisure time pedagogy covers not only education in leisure time, but also education for leisure time, and education via leisure time. One can speak about three dimensions of this education: the first is the education itself (it takes into account specific conditions which are given by the relatively free decision-making of an individual in a particular period of his life), the second is leisure time (its valuable usage is given by motivation, and the developed competences of an individual), and the third are the means of education. ${ }^{131}$ Is this concept of leisure time pedagogy relevant in the current situation where the clear borders between leisure time and work time are disappearing?

If one looks at the lives of children and youth (as a primal target group, see Chapter 5), one can see that leisure time as a time category has not disappeared. The aspect which has been disappearing is the base of leisure time. This base is, to a great extent, influenced by the instrumentalisation of leisure time and by the pedagogical forming of leisure time (Chapter 4). Leisure time has become mandatory. Such a change lowers the potential of leisure time. This development underlines the importance of leisure time pedagogy, which should focus its effort not only on children and youth but also on the education of parents and pedagogues of leisure time, who are (in many aspects) responsible for the instrumentalisation and for the pedagogical forming of leisure time (Chapter 5).

Leisure time is also a time of freedom, and this attribute should not be taken away. This is not a freedom which is taken out of the context of our society, it is a freedom which enables one to form a value base in connection with one's personal experience, and in the context of one's social group. It is also a freedom which exposes one to the necessity of consideration, to the process of decision-making, and which provides space for the acknowledgement of the consequences of one's decisions (involving either the individual himself, or even whole groups). In this way, an individual learns how to consider matters in a wider context (social as well as temporal), and to accept responsibility for his own decisions. One can even experience the paradox of freedom, that is, he can freely limit his freedom. This can have two reasons: either he profits from such a decision, or he does it for the benefit of others. In this way, children can learn how to work with their freedom in the context of their life or society. As one can see, leisure time has a huge potential for formation. On the other hand, the possibility of formation can be endangering especially when the intentional formation pushes away the unintentional and spontaneous one. Leisure time pedagogy has its place in current society. The changing elements (considering the development of society) are its aims, methods, or forms of work. It is not just a meaningful spending of leisure time. It rather includes value education, development of leisure time com-

129 Cf. BAUMAN, Východiska...

130 Cf. KAPLÁNEK, Pedagogika...

131 Cf. BAUMAN, Východiska... 
petences, development of critical thinking, and socialisation. Weisure lifestyle does not make leisure time pedagogy less significant. Conversely, the role of education for leisure time is emphasised. Without leisure time, the quality of life of an individual and even of the whole society is endangered. The emphasis is on education within leisure time as it is a space where one can focus more on searching for the meaning of life - a process which cannot be fulfilled during the time of duties. Education via leisure time is no less significant as the basic attribute of leisure time is freedom - the best tool for teaching a contemporary person how to manage his own freedom in the context of his life and society.

\section{Contact:}

\section{Mgr. Martina Kočerová}

Department of Pedagogy, Faculty of Theology, University of South Bohemia in České Budějovice Kněžská 8, 37001 České Budějovice martina.kocerova@tf.jcu.cz 